\title{
Surface Subsidence Control during Deep Backfill Coal Mining: A Case Study
}

\author{
Baiyi Li, ${ }^{1,2}$ Nan Zhou $\mathbb{D}^{1,2}$ Wenyue Qi $\mathbb{D}^{3,4}$ Ailing Li, ${ }^{1,2}$ and Zhizhong Cui ${ }^{1,2}$ \\ ${ }^{1}$ State Key Laboratory of Coal Resources and Safe Mining, Xuzhou 221116, China \\ ${ }^{2}$ School of Mines, China University of Mining and Technology, Xuzhou 221116, China \\ ${ }^{3}$ Metastable Materials Science and Technology SKL, Qinhuangdao 066004, China \\ ${ }^{4}$ Key Laboratory of Mechanical Reliability for Heavy Equipments and Large Structures of Hebei Province, Yanshan University, \\ Qinhuangdao 066004, China
}

Correspondence should be addressed to Nan Zhou; zhounanyou@126.com

Received 23 October 2018; Revised 26 March 2019; Accepted 5 December 2019; Published 29 May 2020

Academic Editor: Trung Ngo

Copyright (c) 2020 Baiyi Li et al. This is an open access article distributed under the Creative Commons Attribution License, which permits unrestricted use, distribution, and reproduction in any medium, provided the original work is properly cited.

\begin{abstract}
Deep resource exploitation is imperative, but it is facing with more complicated mining environment and more dangerous mining disturbances to induce the potential catastrophe process. Solid backfill technology, which can control the strata movement and prevent potential hazards, has been used as the primary method in deep mining for surface subsidence control and ecosystem protection. In this study, taking backfill mining area no. 930 in the Tangkou coal mine as background, the probability integral model was adopted to predict the surface subsidence at different mining depths and filling ratios. The filling ratio was designed for deep mining based on the regression analysis of the predicted surface subsidence results. The study shows that the backfilling ratio at the Tangkou deep coal mining area should be controlled at a level greater than $82.5 \%$, and the mining damage to the surface under this condition was analyzed. Furthermore, control strategies for deep backfill mining are proposed in which the backfill density can be enhanced by optimizing the tamping machine, material composition, and tamping process. Finally, the measurement of the backfill mass and surface subsidence showed that the actual filling ratio was controlled at $82.57 \%$, which ensures adequate protection of the surface buildings during the mining process.
\end{abstract}

\section{Introduction}

With the continuous high-intensity extraction from shallow coal mines and gradual exhaustion of coal resources in eastern China, exploitation of coal resources drives deeper underground at a rate of $10-25 \mathrm{~m} / \mathrm{a}$ [1]; thus, deep mining is gradually becoming a common practice in the coal industry and in natural resource extraction $[2,3]$. The increasing depth of resource extraction, in particular, for coal mining at a depth of 1000-2000 m may potentially lead to more severe mining hazards including higher frequency and stronger intensity of rock burst, more dangerous coal and gas outburst, increasing mining pressure, higher risks of water invasion, and increasing difficulty in predicting surface subsidence. These risks pose significant challenges to deep coal mining and mining hazards prevention practices [4-6].
Solid backfill mining is a particularly promising technology used in coal mining for controlling stratum movement, preventing potential disaster, treating solid waste (coal gangue), controlling surface subsidence, protecting ecosystems, and improving coal extraction rate $[7,8]$. As one of the core techniques used for eco-friendly coal mining, backfilling the vacant space after mine extraction with solid waste such as coal gangue has been used as a primary technique for resolving issues in deep underground natural resource extraction. However, the deep mining occurs in a very different environment from shallow mining as the high ground stress induces different stratum movement mechanisms during the deep backfill mining. In addition, the control of surface subsidence in deep backfill mining differs from that in shallow backfill mining considerably. Most previous studies have examined the surface subsidence in deep mining. Fan et al. [9-11] 
proposed an approach combining differential interferometric synthetic aperture radar (D-InSAR) results and probability integral model (PIM) results, to generate the entire mining subsidence basin. Jiřina and Šperl [12] studied the possibility of filling empty underground spaces, which exist due to the extraction of mineral raw materials, with fly ash and cement fly ash mixes for the purpose of reducing the impact of deep mining on the surface. Chang et al. [13] analyzed the surface dynamic subsidence characteristics under deep mining subsidence and the maximum subsidence velocity based on the monitoring data of surface subsidence in 230 mining areas of the Tangkou coal mine. Chen et al. [14] introduced the theories and application principles of five types of integrated surface subsidence-reducing technologies. Guo et al. [15] and Zhang [16] proposed a probability integral model for surface subsidence prediction based on the equivalent mining height (EMH) theory and described the basic control principle for surface subsidence. Most of these studies only targeted deep mining or backfill mining separately. To date, exploration of surface subsidence control in deep backfill mining is still lacking.

Taking backfill mining area no. 930 in the Tangkou coal mine as background, the probability integral model was adopted to analyze the predicted surface subsidence at different mining depths and filling ratios. We established an engineering design method of the filling ratio for deep mining based on the regression analysis of the predicted surface subsidence results. Also, based on the security standard for surface buildings, we propose control methods of the backfill body's density for mining area no. 930 in the Tangkou coal mine. The actual backfill density and surface subsidence were measured to verify the accuracy of the result. The findings from this study are of great significance for realizing safe, efficient, and eco-friendly coal extraction from deep underground areas.

\section{Research Background}

2.1. Mining Geological Condition. The Tangkou coal mine, belonging to the Shandong Energy Zibo Mining Group Co., Ltd., is located in Jining City, Shandong Province, China, and the longwall mining method is mainly used in this mine. However, with the increase of production life, the mining depth has extended to $1098-1220 \mathrm{~m}$. Currently, the mining area is the no. 930 area, which is located at about $670 \mathrm{~m}$ south of the industrial square, north of the Beijing-Hangzhou grand canal, east to Xingfugou, and the western boundary is located $96 \mathrm{~m}$ west of the Limiao village. The upper part of the mining area is almost covered by the Limiao village and Fengtai village, and the ruins of the Phoenix Palace are located in the middle of the mining area. The mining area covers around $0.85 \mathrm{~km}^{2}$ area with a total coal reserve of 4.067 million tons. The immediate roof and the immediate floor of the coal seam are mudstone, with an average thickness of $3.77 \mathrm{~m}$ and $1.50 \mathrm{~m}$, respectively. The compressive strength is about $30 \mathrm{MPa}$, which is unstable. In order to protect the landmark buildings from being damaged, coal mining technique with gangue filling is adopted to mine coal resources. A total of 9 working faces are arranged, with the surface length of $60 \mathrm{~m} \sim 80 \mathrm{~m}$, as shown in Figure 1 .
2.2. Overview of Surface Buildings. Five villages (Fengtai, Sunjia, Limiao, Wujia, and Huangjingcun) and the Tangkou coal industrial plaza are located within the zone of influence of mining activity at mining area 930. These villages, covering an area of $2.241 \times 10^{5} \mathrm{~m}^{2}$, have a total of 1545 residents, a population of 5300, and a total of 2248 buildings. In addition, Fenghuangtai Ruin, a provincial key cultural relic protected unit, is located at the Fengtai village. The Tangkou coal industrial plaza, covering a total area of $1.62 \times 10^{4} \mathrm{~m}^{2}$, holds a miners' canteen, dormitory buildings, and an electrical substation. Most of the buildings within the zone of mining influence are either constructed with a masonry structure or multifloor buildings with a reinforced concrete frame structure. Summary of all the buildings and its satellite images are shown in Table 1 , respectively.

\section{The Characteristics of Surface Deformation Induced by Deep Backfill Mining}

The main difference in surface subsidence between deep backfill mining and shallow backfill mining is illustrated in the following aspects. First, the filling material deformation and mining pressure in deep backfill mining are much larger due to the presence of high ground stress. With increasing mining depth, the maximum surface deformation is reduced, but the zone of influence keeps increasing in diameter and is accompanied by an increment in the total influencing area from the surface subsidence [17]. In addition, the critical mining area required for reaching full subsidence at the surface also increases. Meanwhile, the overlying strata and the upper, lower, and isolating coal columns in the mining area are found to have a more significant impact on controlling the surface subsidence.

3.1. Methodology. The probability integral model (PIM) is a prediction theory of mining subsidence that has been widely used in China $[18,19]$. The PIM was still adopted in the prediction of backfill mining subsidence. According to the principle of the probability integral method, the subsidence of any surface point $(\mathrm{x}, \mathrm{y})$ caused by backfill mining can be expressed as [20-22]

$$
w(x, y)=M_{e} q \iint_{\Omega} \frac{1}{r^{2}} \exp \left[-\pi \frac{\left(x-x_{i}\right)^{2}+\left(y-y_{i}+H_{i} \operatorname{ctg} \theta\right)^{2}}{r^{2}}\right] \mathrm{d} x \mathrm{~d} y,
$$

where $q$ is the subsidence coefficient; $r$ is the main influence radius, $r=\left(H_{0} / \tan \beta\right) ; H_{0}$ is the average mining depth; $H_{i}$ is the depth of mining unit $i$; $\theta$ is the mining influence angle; $\tan \beta$ is the tangent of the main influence angle; $\left(x_{i}, y_{i}\right)$ is the planar coordinate of mining unit $i ;(x, y)$ is the coordinate of any surface point; and $M_{e}$ is the equivalent mining height of solid backfill mining. The horizontal displacement, inclination, curvature, and horizontal deformation can be obtained through the integration calculation.

In order to use this model to obtain the full subsidence basin, it is necessary to confirm the prediction parameters $M_{e}, q, \tan \beta, \theta, s$, and $b$. Here, $b$ is the parameter of horizontal movement, and it was usually assumed to be 0.35 by 


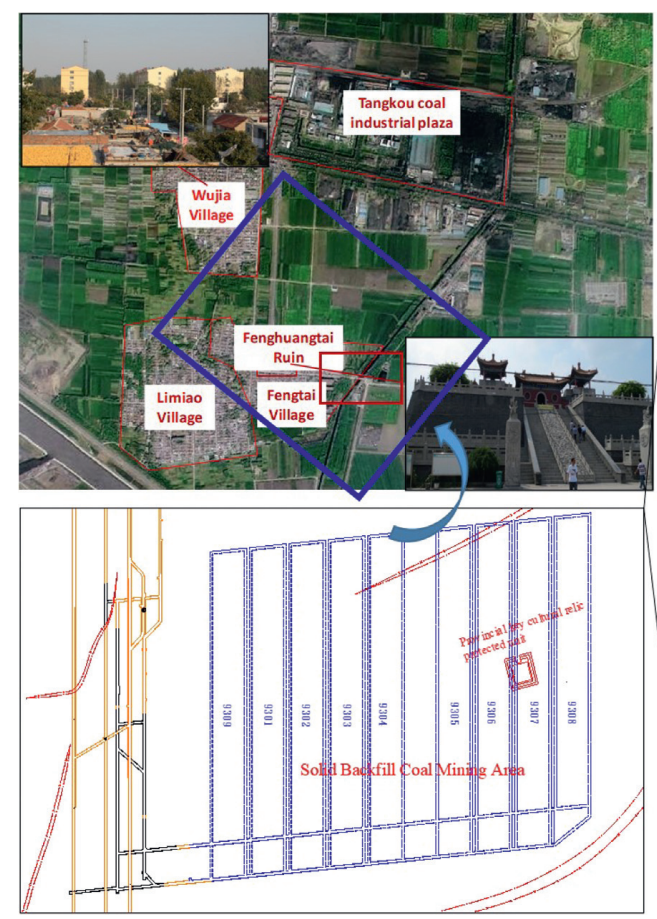

\begin{tabular}{|c|c|c|}
\hline $\begin{array}{c}\text { Bar } \\
(1: 200)\end{array}$ & $\begin{array}{c}\text { Rock } \\
\text { formation }\end{array}$ & $\begin{array}{c}\text { Thickness } \\
(\mathrm{m})\end{array}$ \\
\hline & $\begin{array}{c}1 \# \\
\text { mudstone }\end{array}$ & 9.70 \\
\cline { 2 - 3 } & $\begin{array}{c}\text { 2\# sandy } \\
\text { mudstone }\end{array}$ & 2.40 \\
\hline $\begin{array}{c}3 \# \\
\text { mudstone }\end{array}$ & 2.70 \\
\hline $\begin{array}{c}\text { 4\# medium } \\
\text { sandstone }\end{array}$ & 9.10 \\
\hline $\begin{array}{c}5 \# \\
\text { mudstone }\end{array}$ & 2.20 \\
\hline $\begin{array}{c}\text { 6\# medium } \\
\text { sandstone }\end{array}$ & 1.60 \\
\hline $\begin{array}{c}7 \# 3 \text { coal } \\
\text { 8\# } \\
\text { mudstone }\end{array}$ & 3.50 \\
\hline $\begin{array}{c}9 \# \text { medium } \\
\text { sandstone }\end{array}$ & 0.80 \\
\hline & 0.20 \\
\hline
\end{tabular}

Figure 1: Location of the Tangkou coal mine and layout of the 930 mining area.

TABLE 1: Summary of the buildings near Fenghuangtai and surrounding villages.

\begin{tabular}{|c|c|c|c|c|c|c|c|c|}
\hline \multirow[b]{2}{*}{ Number } & \multirow[b]{2}{*}{ Village } & \multirow[b]{2}{*}{ Affiliation } & \multirow[b]{2}{*}{ Households } & \multirow[b]{2}{*}{ Population } & \multirow{2}{*}{$\begin{array}{c}\text { Area of } \\
\text { buildings } \\
\left(\times 10^{4} \mathrm{~m}^{2}\right)\end{array}$} & \multicolumn{3}{|c|}{ Number of buildings per structure } \\
\hline & & & & & & $\begin{array}{l}\text { Adobe } \\
\text { cottage }\end{array}$ & $\begin{array}{l}\text { Masonry } \\
\text { house }\end{array}$ & $\begin{array}{c}\text { Multifloor } \\
\text { building }\end{array}$ \\
\hline 1 & Fengtai & & 398 & 1193 & 5.77 & 36 & 326 & 36 \\
\hline 2 & Sunjia & Nanzhang Street, & 236 & 1039 & 3.42 & 21 & 194 & 21 \\
\hline 3 & Limiao & Rencheng District, & 637 & 1997 & 9.24 & 57 & 522 & 57 \\
\hline 4 & Wujia & Jining & 146 & 569 & 2.12 & 13 & 120 & 13 \\
\hline 5 & Huangjingcun & & 128 & 502 & 1.86 & 15 & 102 & 10 \\
\hline 6 & $\begin{array}{l}\text { Tangkou coal } \\
\text { industrial plaza }\end{array}$ & $\begin{array}{c}\text { Tangkou Coal Co., } \\
\text { Ltd. }\end{array}$ & - & - & 1.62 & - & - & - \\
\hline & Total & & 1545 & 5300 & 24.03 & 143 & 1264 & 841 \\
\hline
\end{tabular}

trial and error; $s$ is offset of inflection points. However, the prediction parameters associated with the traditional caving method cannot be adopted directly as parameters in the prediction model for surface subsidence in backfill coal mining. For solid backfill mining, the subsidence is caused by mining coal with an equivalent height that is the mining height of filling working face minus the height of filling material after compaction [17, 23], and the equation for calculating the equivalent mining height is shown in the following formula:

$$
M_{e}=h_{z}+\left(k-k^{\prime}\right)\left(M-h_{z}\right),
$$

where $h_{z}$ is the unfilled height in goaf; $M$ is the mining height, $3.31 \mathrm{~m}$; $k$ is the initial porosity of the filling material measured to be 1.15 from the experiments; and $k^{\prime}$ is the residual porosity after compaction measured to be 1.05 from the experiments.

The subsidence coefficient of solid backfill mining based on the equivalent mining height can be expressed as
$q=q_{c}+\frac{\left[H_{1}\left(k_{1}-1\right)+\left(H_{2}-H_{2}^{\prime}\right)\left(k_{2}-1\right)+\left(H_{3}-H_{3}^{\prime}\right)\left(k_{3}-1\right)\right]}{M_{e}}$,

where $q_{c}$ is the subsidence coefficient of caving coal mining, which is the ratio of the maximum subsidence with mining height under fully extraction; $H_{1}, H_{2}$, and $H_{3}$ are heights of collapse, fracture, and sagging zones, respectively; $H_{2}^{\prime}$ and $H_{3}^{\prime}$ are the heights of the fracture zone and sagging zone by solid backfill mining; and $k_{1}, k_{2}$, and $k_{3}$ are bulking factors of collapse, fracture, and sagging zones correspondingly.

$\tan \beta, \theta, s$, and $b$ share similar values with those used in the fully caving coal mining method. The measurements of surface movement at extraction areas 130,230, and 430 in the Tangkou coal mine revealed a gradual and continuous movement of the earth's surface induced by the fully caving coal mining operation at the working area in the third coal seam layer. The measurement results were also found to correspond with the distribution calculated from the 
probability integral method. The prediction parameters used in the probability integral method were obtained by the inverse genetic algorithm [24] as shown in Table 2.

In summary, based on the inverse calculation of the parameters for surface movement induced by fully caving coal mining, the prediction parameters for surface subsidence at backfill mining area no. 930 in the Tangkou coal mine can be determined as $q=0.82, b=0.35, \tan \beta=2.15$, $s=0.036 \mathrm{H}$, and $\theta=90^{\circ}-0.46 \alpha$ ( $\alpha$ is the inclination angle of the coal seam).

3.2. Surface Subsidence under Different Backfill Mining Conditions. The ground surface deformation pattern was explored under different backfill mining depth conditions. Specifically, the authors analyzed the surface deformation characteristics with a depth of $300 \mathrm{~m}, 500 \mathrm{~m}, 700 \mathrm{~m}, 900 \mathrm{~m}$, and $1100 \mathrm{~m}$. For all cases, the backfill body's filling ratio was fixed at $80 \%$, which is equivalent to a mining thickness of $0.93 \mathrm{~m}$. Table 3 and Figure 2 summarize the prediction for surface subsidence under different conditions. (Number is measuring points which were arranged twenty meters apart passing through the middle of the work surface.)

With a fixed filling ratio, a similar trend was observed between solid backfill mining and fully caving mining where the maximum ground surface subsidence decreases logarithmically with increasing mining depth, $y=-337.2 \ln (H)+2780$. In addition, the horizontal movement decreases exponentially with increasing mining depth with a relatively small change compared to the surface subsidence. Furthermore, a greater mining depth also resulted in a reduced level of mining completeness. This effect, acting directly on the overlying stratum, is attenuated after each layer which eventually leads to a much smaller impact on the ground surface. The zone of influence increases exponentially with increasing mining depth. This is because the effect of mining on the overlying stratum is amplified after each layer which ultimately resulted in a much stronger impact on the ground surface.

\subsection{Surface Subsidence Prediction with Different Filling Ratios.} The ground surface deformation pattern was explored with different filling ratios. The backfilling depth was fixed at $1100 \mathrm{~m}$, and the filling ratio was varied between $0 \%, 60 \%$, $70 \%, 80 \%$, and $90 \%$, which corresponded to an equivalent mining height of $3.13 \mathrm{~m}, 1.52 \mathrm{~m}, 1.23 \mathrm{~m}, 0.93 \mathrm{~m}$, and $0.63 \mathrm{~m}$, respectively. Table 4 and Figure 3 summarize the prediction values of the ground surface subsidence.

As shown in the result, the ground surface subsidence and horizontal movement decrease exponentially with increasing filling ratio, and the fitting formulas are $y=2662.8 e^{-2.209} \varphi$ and $y=1811.1 e^{-2.931} \varphi$, respectively. Compared with fully caving mining methods, the solid backfill mining method yields a much smaller maximum moving and deforming magnitude. Therefore, the solid backfill mining induces minor impact on ground surface which effectively secures the safety of surface buildings.

\section{The Design and Control of the Filling Ratio in Deep Mining at Tangkou Coal Mine}

4.1. Design of Filling Ratio in Deep Mining at Tangkou Coal Mine. Using SPSS fitting, the authors obtained the regression equation (see equation (4)) with surface subsidence as a dependent variable and mining depth and filling ratio as independent variables. The change in surface subsidence as a function of mining depth and filling ratio is shown in Figure 4:

$$
w=\left[3.61 e^{-0.47 \varphi}-0.31 \ln (H)+0.12\right] \times 1000,
$$

where $\varphi$ is the filling rate.

According to the regulation in "Coal Pillar and Coal Mining under Building, Water Body, Railway, and Main Roadway Standards" [25], the ground surface building at the Tangkou coal mine belongs to Class I protection building where the maximum allowable surface deformation values are $400 \mathrm{~mm}$ subsidence, $2.5 \mathrm{~mm} / \mathrm{m}$ inclination, $1.5 \mathrm{~mm} / \mathrm{m}$ horizontal deformation, and $20 / \mathrm{km}$ curvature. As shown in Tables 3 and 4, the inclination, horizontal deformation, and curvature fully satisfied the requirement when the filling ratio is greater than $70 \%$. If the surface subsidence was set as the indicator, a backfilling depth of $1098 \sim 1220 \mathrm{~m}$ requires a filling ratio of $82.5 \% \sim 79.7 \%$ to ensure safety. Therefore, the filling ratio at backfill mining area 930 in the Tangkou coal mine should be designed with a value greater than $82.5 \%$.

4.2. Damage Analysis for Backfill Mining. Table 5 shows the surface subsidence value predicted using a filling ratio of $82.5 \%$. Figure 5 shows an isocontour map of surface subsidence. Based on the damage rating for masonry buildings, the building damage associated with the maximum surface subsidence of $394 \mathrm{~mm}$ falls in the minor level I damage range. Therefore, the maximum surface subsidence predicted in the study was controlled in idea scope below the critical deformation value required for inducing permanent damage to the masonry buildings. Hence, backfill mining will not cause any significant risk to the safety and normal operation of surface buildings.

4.3. Method of Guaranteeing Filling Ratio. In this paper, the filling rate was guaranteed by controlling the gradation of filling materials, optimizing the tamping angle and times of the tamping institution, and improving the filling process $[16,26]$. The specific implementation methods are as follows.

4.3.1. Optimizing Filling Material Composition. The compaction characteristics of coal gangue used for backfilling at mining area no. 930 at the Tangkou coal mine were analyzed using an electro-hydraulic servo universal testing machine. The compaction-deformation curves of coal gangue with six different maximum diameters $(0-10 \mathrm{~mm}, 0-20 \mathrm{~mm}$, $0-30 \mathrm{~mm}, 0-40 \mathrm{~mm}, 0-50 \mathrm{~mm}$, and $0-80 \mathrm{~mm}$ ) were obtained and are shown in Figure 6. As shown in the result, the compaction deformation increases with increasing coal gangue diameter. A higher rising rate in the deformation was 
TABLe 2: Parameters for surface movement induced by fully caving coal mining.

\begin{tabular}{|c|c|c|c|c|c|c|c|c|c|c|c|c|}
\hline Number & $\begin{array}{l}\text { Measuring } \\
\text { line }\end{array}$ & $\begin{array}{c}\text { Working } \\
\text { area }\end{array}$ & $\begin{array}{l}\text { Width } \\
\text { (m) }\end{array}$ & $\begin{array}{l}\text { Gap } \\
(\mathrm{m})\end{array}$ & $\begin{array}{l}\text { Thickness } \\
\text { (m) }\end{array}$ & Stopping time & $\begin{array}{l}\text { Observation } \\
\text { time }\end{array}$ & $q_{c}$ & $\tan \beta$ & $\theta$ & $s$ & $\begin{array}{l}q_{c} \\
\text { relative } \\
\text { error } \\
(\%)\end{array}$ \\
\hline & $\begin{array}{l}\text { East-west } \\
\text { measuring }\end{array}$ & 1301 & 215 & 220 & $2.77 \sim 3.45$ & 2005.10 2006.11 & $2005.12 \sim 2008.11$ & 0.52 & 2.10 & 0.46 & 0 & -0.36 \\
\hline 1 & $\begin{array}{l}\text { line in } \\
\text { working } \\
\text { area } 1301 \\
\end{array}$ & 1302 & 210 & 220 & 3.67 & $2006.12 \sim 2007.08$ & $2005.12 \sim 2008.11$ & 0.65 & 2.15 & 0.49 & 0 & 0.84 \\
\hline 2 & $\begin{array}{c}\text { South-north } \\
\text { measuring } \\
\text { line in } \\
\text { working } \\
\text { area } 1302\end{array}$ & 1302 & 210 & 220 & 3.67 & $2006.12 \sim 2007.8$ & 2007.01 2009.05 & 0.53 & 2.30 & 0.76 & $\begin{array}{c}30 / \\
0.032 \mathrm{H}\end{array}$ & -0.58 \\
\hline 3 & $\begin{array}{c}\text { South-north } \\
\text { measuring } \\
\text { line in } \\
\text { working } \\
\text { area } 1304\end{array}$ & 1304 & 150 & 130 & 4.97 & 2008.01 2008.11 & $2008.08 \sim 2009.10$ & 0.44 & 2.05 & 0.3 & $\begin{array}{c}45 / \\
0.05 \mathrm{H}\end{array}$ & -0.52 \\
\hline 4 & $\begin{array}{c}\text { South-north } \\
\text { measuring } \\
\text { line in } \\
\text { working } \\
\text { area } 1305\end{array}$ & 1305 & 130 & 130 & $3.45 \sim 6.5$ & $2010.08 \sim 2011.05$ & $2010.07 \sim 2011.03$ & 0.32 & 1.65 & 0.38 & $\begin{array}{c}50 / \\
0.05 \mathrm{H}\end{array}$ & 0.32 \\
\hline \multirow{12}{*}{5} & $\begin{array}{l}\text { East-west } \\
\text { measuring } \\
\text { line in } \\
\text { working } \\
\text { area } \\
2301 \sim 2307\end{array}$ & 2307 & 210 & 100 & $3.48 \sim 3.75$ & 2007.11 2008.07 & $2006.06 \sim 2010.08$ & 0.53 & 2.35 & 0.48 & 0 & -0.36 \\
\hline & $\begin{array}{c}\text { South-north } \\
\text { measuring } \\
\text { line in }\end{array}$ & 2307 & 210 & 100 & $3.48 \sim 3.75$ & 2007.11 2008.07 & $2006.06 \sim 2010.08$ & 0.60 & 2.25 & 0.5 & 0 & 0.42 \\
\hline & $\begin{array}{c}\text { working } \\
\text { area }\end{array}$ & 2305 & 120 & 100 & $2.93 \sim 3.42$ & 2008.11 2009.05 & $2006.06 \sim 2010.08$ & 0.50 & 2.25 & 0.5 & 0 & -1.32 \\
\hline & $2301 \sim 2307$ & & & & & & & & & & & \\
\hline & East-west & 2307 & 210 & 100 & $3.48 \sim 3.75$ & 2007.11 2008.07 & $2007.12 \sim 2011.03$ & 0.65 & 2.25 & 0.5 & 0 & 0.45 \\
\hline & $\begin{array}{l}\text { measuring } \\
\text { line in }\end{array}$ & 2305 & 120 & 100 & $2.93 \sim 3.42$ & $2008.11 \sim 2009.05$ & $2007.12 \sim 2011.03$ & 0.60 & 2.25 & 0.5 & 0 & 0.27 \\
\hline & $\begin{array}{c}\text { working } \\
\text { area } \\
2303 \sim 2309\end{array}$ & 2304 & 120 & 100 & 3.04 & $2009.03 \sim 2009.12$ & $2007.12 \sim 2011.03$ & 0.60 & 2.25 & 0.5 & 0 & 0.32 \\
\hline & South-north & 2308 & 200 & 0 & $3.57 \sim 3.76$ & $2009.10 \sim 2010.08$ & $2007.12 \sim 2011.03$ & 0.78 & 2.25 & 0.5 & 0 & 3.52 \\
\hline & measuring & 2307 & 210 & 100 & $3.48 \sim 3.75$ & $2007.11 \sim 2008.07$ & $2007.12 \sim 2011.03$ & 0.78 & 2.25 & 0.5 & 0 & 3.52 \\
\hline & line in & 2306 & 120 & 100 & $3.3 \sim 3.32$ & 2009.09 2010.04 & $2007.12 \sim 2011.03$ & 0.65 & 2.25 & 0.5 & 0 & 0.54 \\
\hline & working & 2305 & 120 & 100 & $2.93 \sim 3.42$ & $2008.11 \sim 2009.05$ & $2007.12 \sim 2011.03$ & 0.65 & 2.25 & 0.5 & 0 & 0.54 \\
\hline & $\begin{array}{c}\text { area } \\
2303 \sim 2309\end{array}$ & 2304 & 120 & 100 & 3.04 & $2009.03 \sim 2009.12$ & $2007.12 \sim 2011.03$ & 0.65 & 2.25 & 0.5 & 0 & 0.37 \\
\hline \multirow{3}{*}{6} & $\begin{array}{c}\text { South-north } \\
\text { measuring } \\
\text { line in } \\
\text { working } \\
\text { area } 4304 \\
\text { and } 4305\end{array}$ & 4305 & 120 & 100 & 3.2 & 2008.09 2009.02 & $2008.10 \sim 2010.02$ & 0.45 & 1.70 & 0.41 & 0 & -0.59 \\
\hline & $\begin{array}{c}\text { Measuring } \\
\text { line on } \\
\text { Jiliang }\end{array}$ & 4304 & 120 & 100 & $3.09 \sim 3.12$ & 2009.06 2010.06 & 2009.05 2011.05 & 0.50 & 1.80 & 0.37 & 0 & -0.49 \\
\hline & $\begin{array}{c}\text { highway } \\
4304 \text { and } \\
4305\end{array}$ & 4305 & 120 & 100 & 3.2 & 2008.09 2009.02 & $2008.10 \sim 2010.02$ & 0.50 & 1.80 & 0.37 & 0 & -0.49 \\
\hline
\end{tabular}


TABLE 3: Surface deformation characteristics affected by mining depth.

\begin{tabular}{|c|c|c|c|c|c|c|c|c|c|c|}
\hline \multirow{2}{*}{$\begin{array}{l}\text { Mining } \\
\text { depth } \\
(\mathrm{m})\end{array}$} & \multirow{2}{*}{$\begin{array}{l}\text { Surface } \\
\text { subsidence } \\
(\mathrm{mm})\end{array}$} & \multicolumn{2}{|c|}{$\begin{array}{c}\text { Horizontal movement } \\
(\mathrm{mm})\end{array}$} & \multicolumn{2}{|c|}{$\begin{array}{c}\text { Horizontal } \\
\text { deformation }(\mathrm{mm} / \mathrm{m})\end{array}$} & \multicolumn{2}{|c|}{$\begin{array}{l}\text { Inclined deformation } \\
(\mathrm{mm} / \mathrm{m})\end{array}$} & \multicolumn{2}{|c|}{ Curvature $\left(\mathrm{mm} / \mathrm{m}^{2}\right)$} & \multirow{2}{*}{$\begin{array}{c}\text { Zone of } \\
\text { influence } \\
\left(\mathrm{km}^{2}\right)\end{array}$} \\
\hline & & $\begin{array}{c}\text { South- } \\
\text { north } \\
\text { direction }\end{array}$ & $\begin{array}{l}\text { East-west } \\
\text { direction }\end{array}$ & $\begin{array}{c}\text { South- } \\
\text { north } \\
\text { direction }\end{array}$ & $\begin{array}{l}\text { East-west } \\
\text { direction }\end{array}$ & $\begin{array}{c}\text { South- } \\
\text { north } \\
\text { direction }\end{array}$ & $\begin{array}{l}\text { East-west } \\
\text { direction }\end{array}$ & $\begin{array}{c}\text { South- } \\
\text { north } \\
\text { direction }\end{array}$ & $\begin{array}{l}\text { East-west } \\
\text { direction }\end{array}$ & \\
\hline 300 & 867 & 221 & 223 & $2.0 /-2.1$ & $2.1 /-2.6$ & 3.8 & 3.8 & 0.04 & 0.05 & 1.4 \\
\hline 500 & 675 & 209 & 218 & $1.1 /-1.2$ & $1.2 /-1.8$ & 2.2 & 2.3 & 0.01 & 0.02 & 2.52 \\
\hline 700 & 558 & 200 & 203 & $0.8 /-0.8$ & $0.8 /-1.3$ & 1.5 & 1.5 & 0.01 & 0.01 & 4.2 \\
\hline 900 & 486 & 193 & 189 & $0.6 /-0.7$ & $0.6 /-0.9$ & 1.1 & 1.1 & $<0.01$ & $<0.01$ & 5.5 \\
\hline 1100 & 431 & 182 & 174 & $0.5 /-0.8$ & $0.4 /-0.7$ & 0.9 & 1.1 & $<0.01$ & $<0.01$ & 5.96 \\
\hline
\end{tabular}

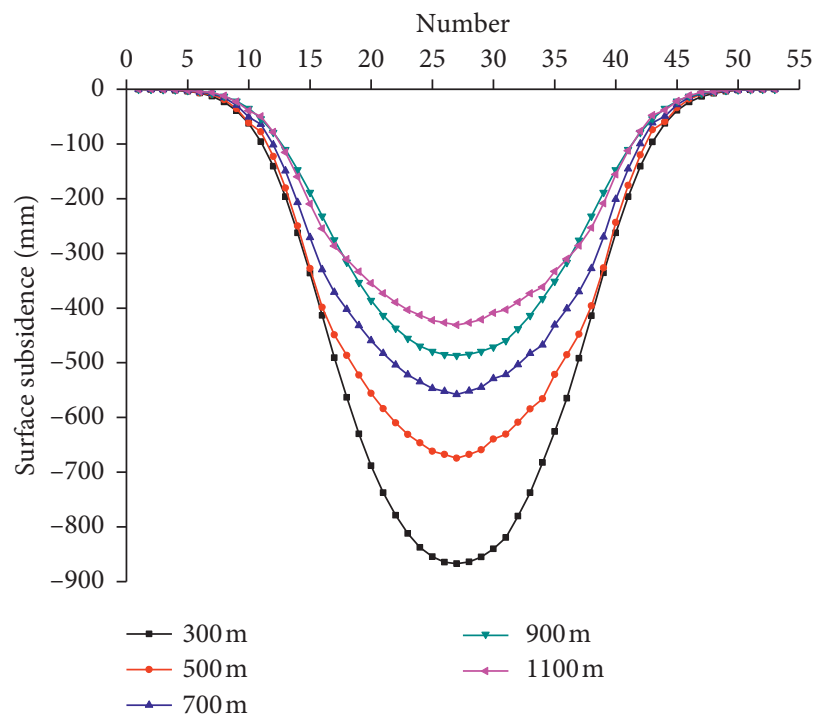

(a)

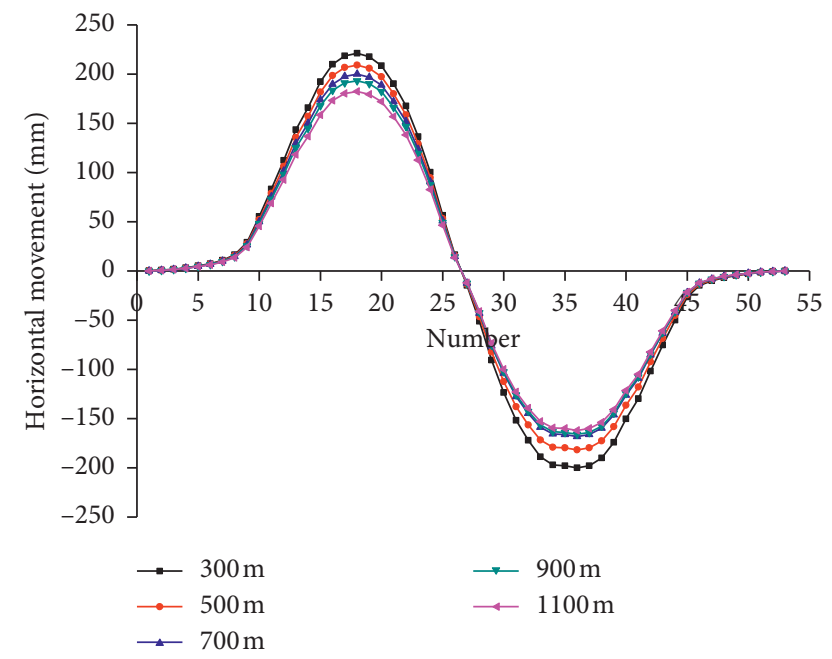

(b)

FIGURE 2: The influence of mining depth on the surface movement in deep backfill mining.

TABLE 4: Surface deformation characteristics affected by the filling ratio.

\begin{tabular}{|c|c|c|c|c|c|c|c|c|c|}
\hline \multirow{2}{*}{$\begin{array}{l}\text { Filling } \\
\text { ratio }(\mathrm{m})\end{array}$} & \multirow{2}{*}{$\begin{array}{l}\text { Surface } \\
\text { subsidence } \\
\quad(\mathrm{mm})\end{array}$} & \multicolumn{2}{|c|}{$\begin{array}{l}\text { Horizontal movement } \\
(\mathrm{mm})\end{array}$} & \multicolumn{2}{|c|}{$\begin{array}{l}\text { Horizontal deformation } \\
\qquad(\mathrm{mm} / \mathrm{m})\end{array}$} & \multicolumn{2}{|c|}{$\begin{array}{l}\text { Inclined deformation } \\
\qquad(\mathrm{mm} / \mathrm{m})\end{array}$} & \multicolumn{2}{|c|}{ Curvature $\left(\mathrm{mm} / \mathrm{m}^{2}\right)$} \\
\hline & & $\begin{array}{l}\text { South-north } \\
\text { direction }\end{array}$ & $\begin{array}{l}\text { East-west } \\
\text { direction }\end{array}$ & $\begin{array}{c}\text { South-north } \\
\text { direction }\end{array}$ & $\begin{array}{l}\text { East-west } \\
\text { direction }\end{array}$ & $\begin{array}{l}\text { South-north } \\
\text { direction }\end{array}$ & $\begin{array}{l}\text { East-west } \\
\text { direction }\end{array}$ & $\begin{array}{l}\text { South-north } \\
\text { direction }\end{array}$ & $\begin{array}{l}\text { East-west } \\
\text { direction }\end{array}$ \\
\hline 0 & 1575 & 651 & 622 & $1.7 /-2.7$ & $1.6 /-2.5$ & 3.1 & 2.9 & 0.01 & 0.01 \\
\hline $60 \%$ & 724 & 300 & 286 & $0.8 /-1.3$ & $0.7 /-1.2$ & 1.4 & 1.4 & 0.01 & 0.01 \\
\hline $70 \%$ & 563 & 241 & 230 & $0.6 /-1.0$ & $0.6 /-0.9$ & 1.1 & 1.1 & $<0.01$ & $<0.01$ \\
\hline $80 \%$ & 431 & 182 & 174 & $0.5 /-0.8$ & $0.4 /-0.7$ & 0.9 & 1.1 & $<0.01$ & $<0.01$ \\
\hline $90 \%$ & 379 & 124 & 118 & $0.3 /-0.5$ & $0.3 /-0.5$ & 0.6 & 0.6 & $<0.02$ & $<0.02$ \\
\hline
\end{tabular}

observed when the size of coal gangue increased from $0-50 \mathrm{~mm}$ to $0-80 \mathrm{~mm}$. The optimum coal gangue size range was determined to be $0-50 \mathrm{~mm}$, and the natural testing angle was measured to be $37.5^{\circ}$ [27] (Figure 7).

4.3.2. Optimizing Tamping Machine. The hinge height of the tamping machine was increased in the optimization. The new height of the hinge located at the base of the machine was designed to be $900 \mathrm{~mm}$ for ensuring adequate storage space. The maximum swing angle of the tamping machine was designed to be $37^{\circ}$, close to the natural resting angle of the filling material. These design improvements resolve the following three issues: (1) small height of the hinge point connecting tamping machine and the base; (2) lack of storage space in the bottom area; (3) incapability of compressing the coal gangue. By adopting a powerless two-stage tamping structure, the maximum and minimum length of 


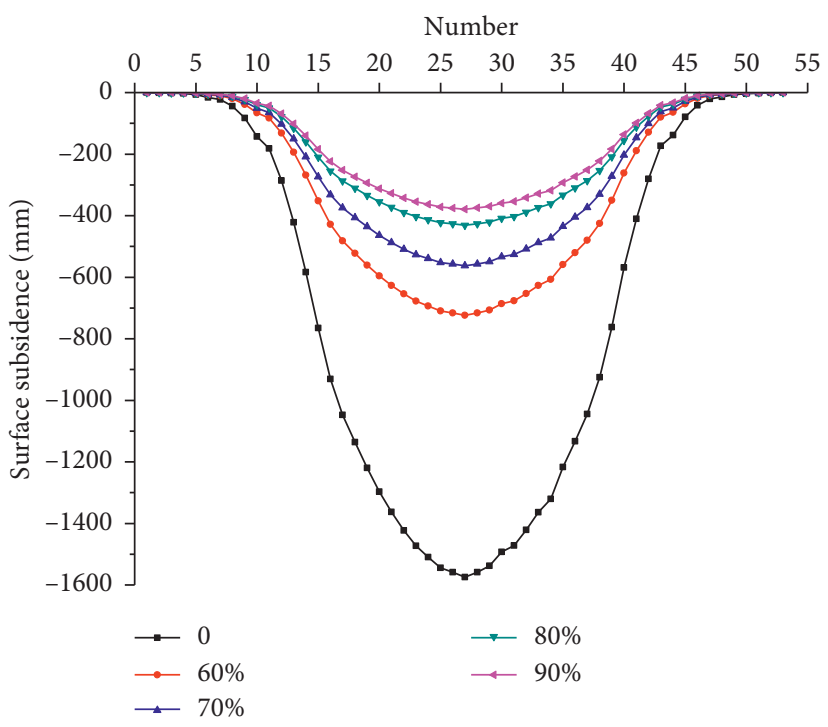

(a)

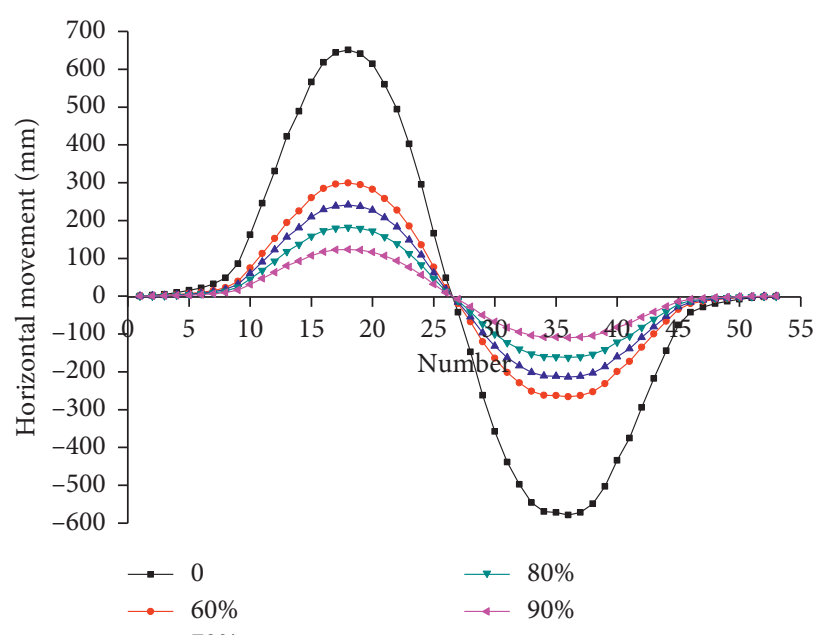

(b)

Figure 3: The influence of filling ratio on the surface movement in deep backfill mining.

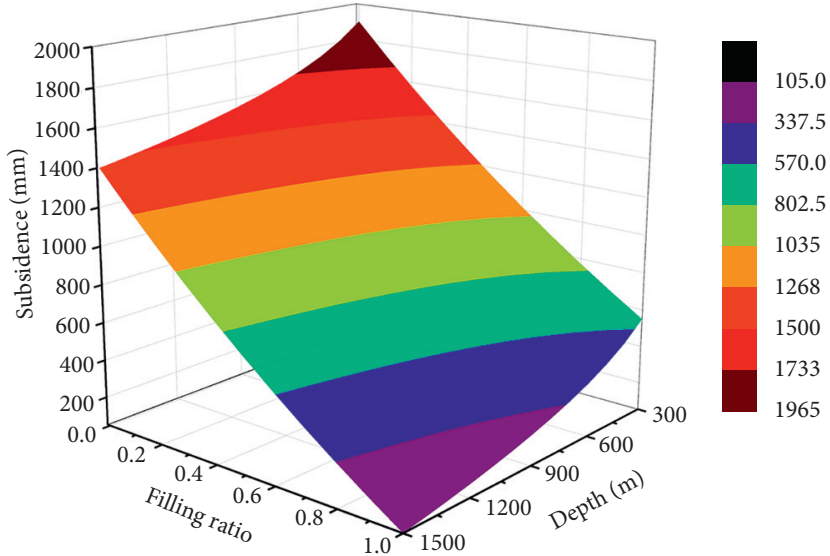

FIgURE 4: Relationship between mining depth, filling ratio, and subsidence.

TABLE 5: Maximum surface movement and maximum deformation.

\begin{tabular}{|c|c|c|c|c|c|c|c|}
\hline \multirow{2}{*}{ Village } & \multirow{2}{*}{$\begin{array}{c}\text { Surface } \\
\text { subsidence }(\mathrm{mm})\end{array}$} & \multicolumn{2}{|c|}{ Horizontal movement $(\mathrm{mm})$} & \multicolumn{2}{|c|}{$\begin{array}{l}\text { Horizontal deformation } \\
\qquad(\mathrm{mm} / \mathrm{m})\end{array}$} & \multicolumn{2}{|c|}{$\begin{array}{l}\text { Inclined deformation } \\
(\mathrm{mm} / \mathrm{m})\end{array}$} \\
\hline & & $\begin{array}{l}\text { South-north } \\
\text { direction }\end{array}$ & $\begin{array}{l}\text { East-west } \\
\text { direction }\end{array}$ & $\begin{array}{l}\text { South-north } \\
\text { direction }\end{array}$ & $\begin{array}{l}\text { East-west } \\
\text { direction }\end{array}$ & $\begin{array}{l}\text { South-north } \\
\text { direction }\end{array}$ & $\begin{array}{l}\text { East-west } \\
\text { direction }\end{array}$ \\
\hline $\begin{array}{l}\text { Limiao village and } \\
\text { Fengtai village }\end{array}$ & 392 & 172 & 160 & $0.38 /-0.47$ & $0.30 /-0.37$ & 0.84 & 0.67 \\
\hline $\begin{array}{l}\text { Sunjia village and } \\
\text { Wujia village }\end{array}$ & 385 & 163 & 157 & $0.47 /-0.50$ & $0.45 /-0.57$ & 0.76 & 0.61 \\
\hline Fenghuangtai & 281 & 118 & 114 & $0.21 /-0.33$ & $0.24 /-0.33$ & 0.61 & 0.43 \\
\hline Limiao new district & 159 & 101 & 95 & $0.17 /-0.32$ & $0.27 /-0.30$ & 0.34 & 0.55 \\
\hline $\begin{array}{l}\text { Limiao elementary } \\
\text { school }\end{array}$ & 112 & 73 & 64 & $0.41 /-0.33$ & $<0.1$ & 0.53 & 0.24 \\
\hline Huangjing village & 27 & 32 & $<10$ & $0.25 /-0.18$ & $<0.1$ & 0.16 & $<0.1$ \\
\hline Qudui office building & 0 & 0 & 0 & 0 & 0 & 0 & 0 \\
\hline 1 dormitory & 0 & 16 & 0 & $0.09 / 0$ & 0 & 0 & 0 \\
\hline 2 dormitory & 0 & 0 & 0 & 0 & 0 & 0 & 0 \\
\hline Electrical substation & 0 & 0 & 0 & 0 & 0 & 0 & 0 \\
\hline Canteen & 13 & 24 & 0 & $0.17 / 0$ & 0 & 0 & 0 \\
\hline Maximum value & 394 & 175 & 167 & $0.46 /-0.72$ & $0.41 /-0.65$ & 0.86 & 0.84 \\
\hline
\end{tabular}




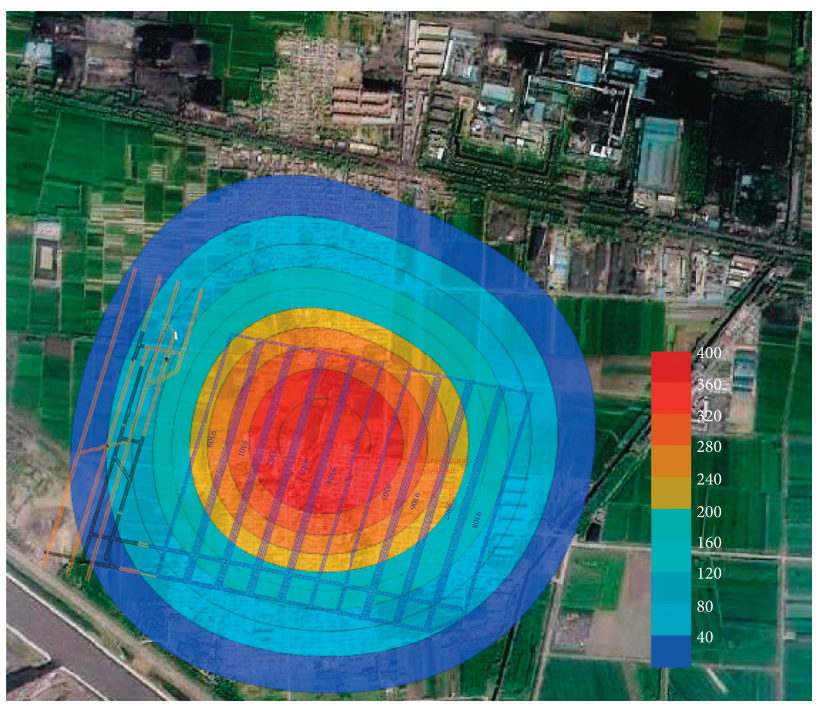

(a)

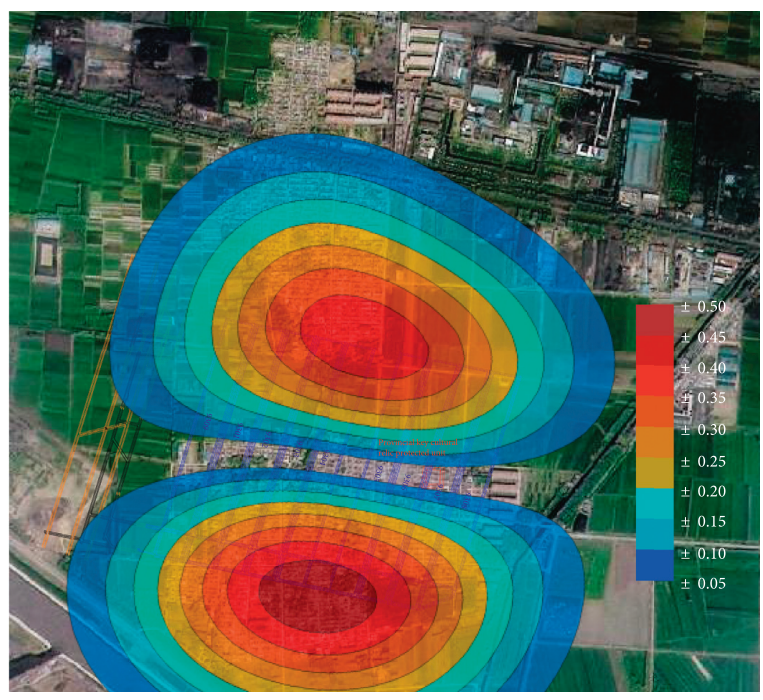

(b)

Figure 5: Depth of mining and the rate of subsidy affect the subsidence. (a) Surface subsidence. (b) Surface horizontal movement.

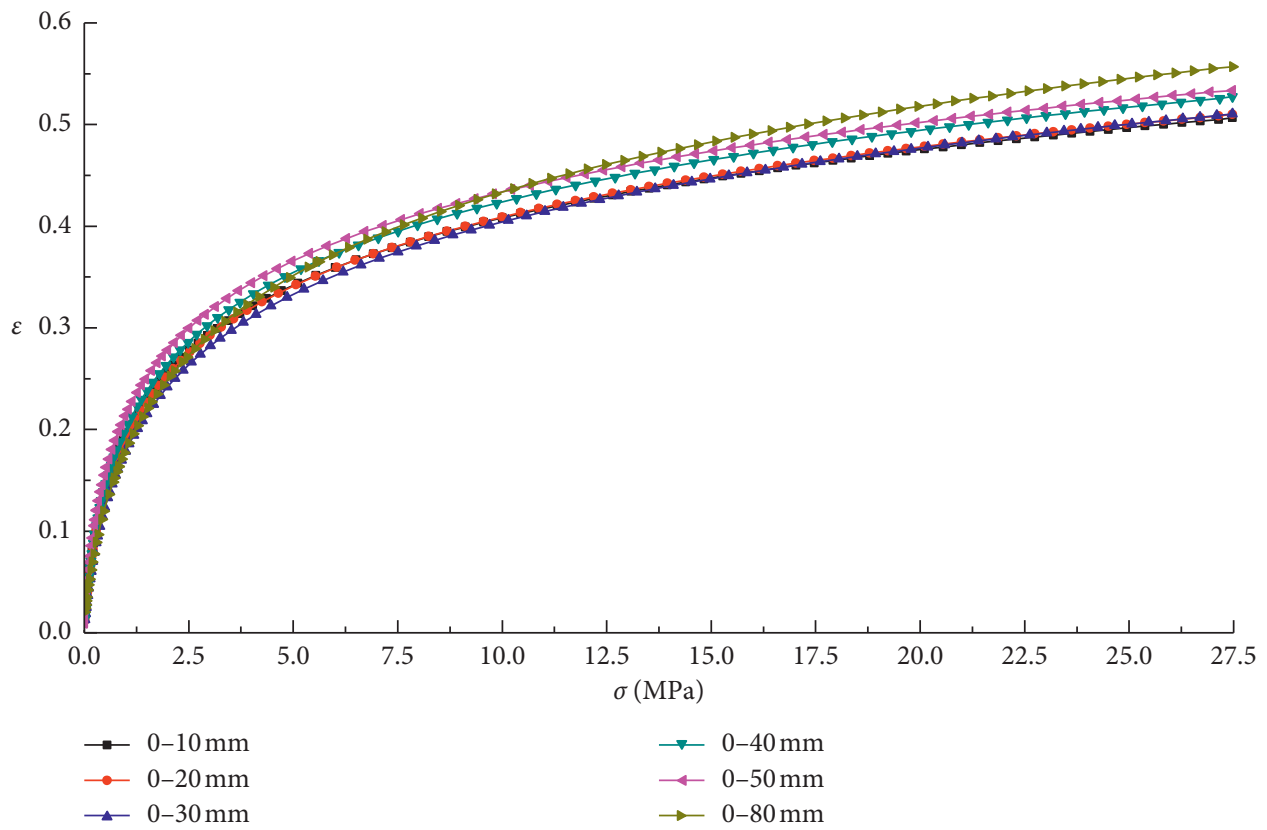

FIgURE 6: Stress-strain curves of coal gangue with different sizes.

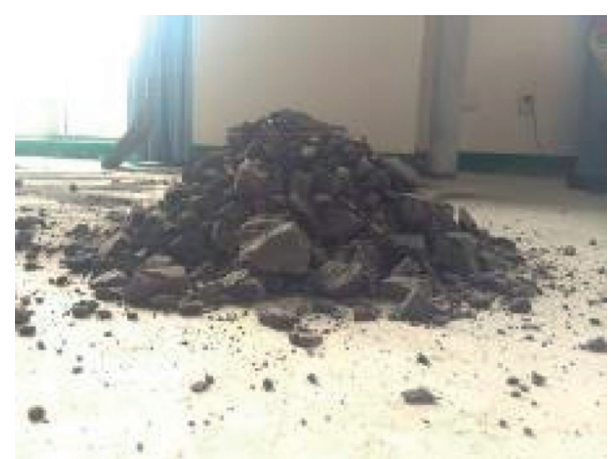

FIgURE 7: Test of the natural testing angle. 


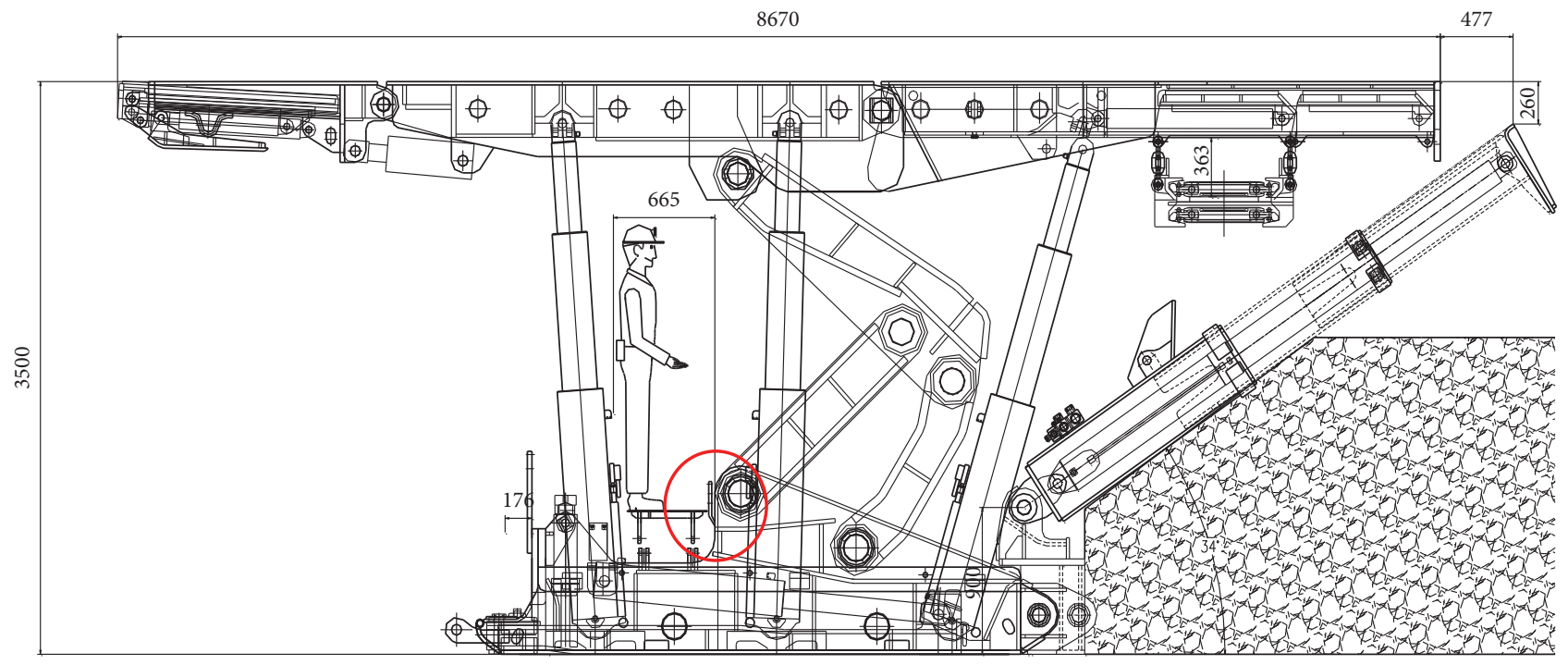

FIGURE 8: Optimized tamping machine.

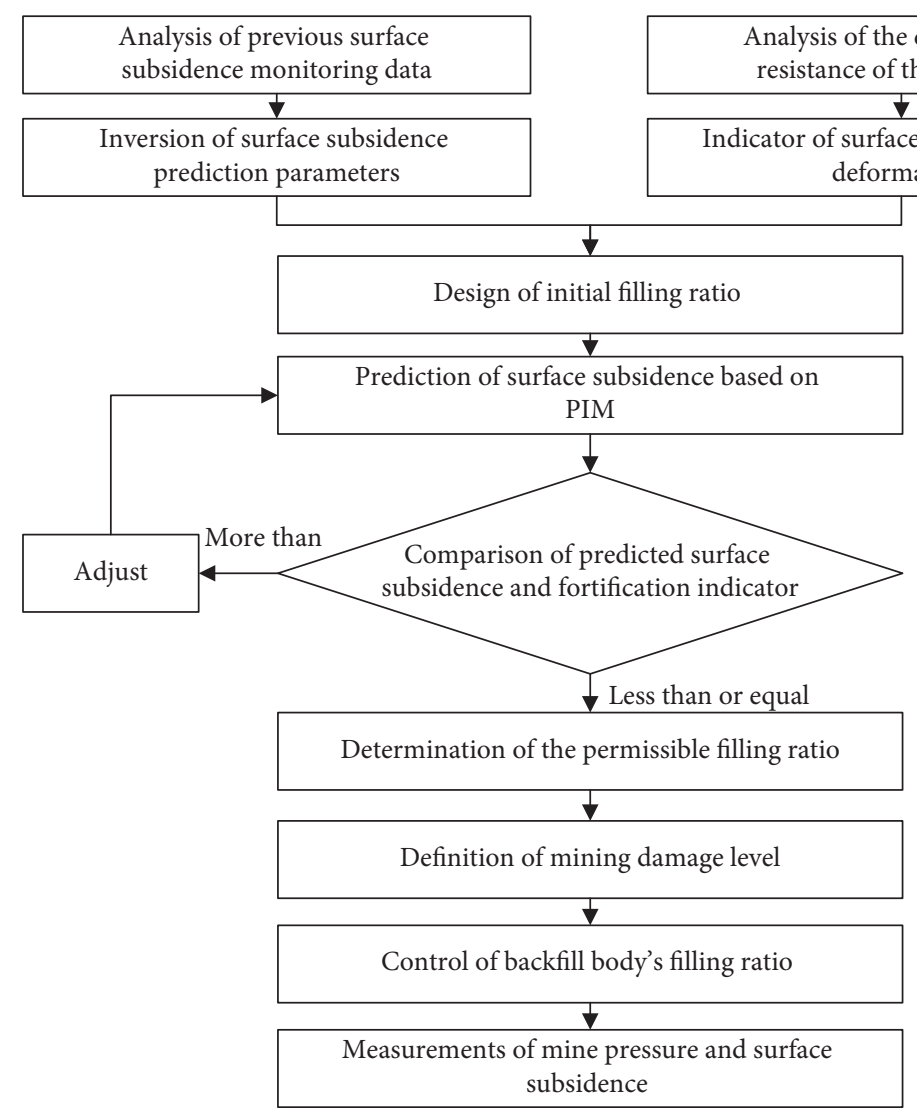

FIGURE 9: Design process for surface subsidence control of deep solid backfill mining under buildings.

the tamping machine can now reach $3971 \mathrm{~mm}$ and $1948 \mathrm{~mm}$, respectively. This design addresses the issue of filling material shortage at the front end of the tamping board when the tamping machine is too long. Figure 8 shows the optimized tamping machine.
4.3.3. Optimizing Tamping Process. The backfilling process follows directly after the mining process. A multihole bottom-unloading conveyor is placed at the rear part of the rear top beam on the supporting stand. When one unloading hole reaches a predetermined height, the second unloading 


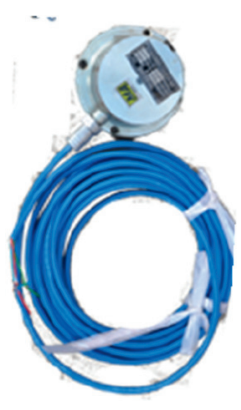

(a)

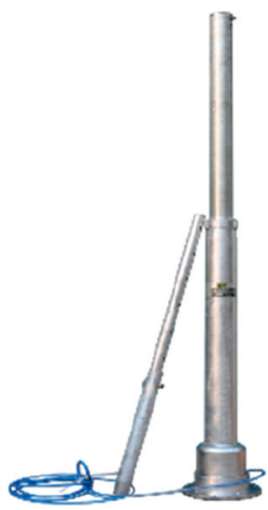

(b)

FIGURE 10: Monitoring instruments and implementation plans. (a) Filling body stress monitor. (b) Roof dynamic monitors.

hole is opened immediately, followed by tamping on the filling material unloaded from the first unloading hole. This process is repeated until all the filling materials are tamped properly. After the first backfilling cycle is finished, a new multihole bottom-unloading conveyor is then transported to the rear part of the rear top beam on the supporting stand followed by the second cycle of refilling. The tamping process using a single supporting stand proceeds, repeating material unloading and tamping cycles in which the filling materials are immediate tamped after unloading.

4.4. Surface Subsidence Prevention Design Process. The process of designing an operation for deep backfill coal mining under buildings is established as shown in Figure 9. First, according to the subsidence monitoring data and deformation resistance of the buildings, the initial filling ratio is determined on the basis of the surface movement and deformation. Second, based on the prediction model of PIM and inverted predicted parameters, comparing the predicted value with the fortification indicator, thus the permissible filling ratio is determined. Finally, the engineering parameters are confirmed based on the grade of mining damage, and measurements of mine pressure and surface subsidence provide feedback information, thereby ensuring the safety of surface buildings through the adjustment of the filling ratio.

\section{Measurement of Refilling Mass and Surface Subsidence at Tangkou Coal Mine}

5.1. Monitor Refilling Mass. The GPD30 filling body stress monitor (Figure 10(a)) and GUD500 roof dynamic monitors ((Figure 10(b)) were installed to monitor the refilling mass, and the measurement results are shown in Figure 11. The roof deformation is consistent with the variation trend of the pressure bear by the backfill. As the load of the backfill increases, the deformation of the roof increases. The changing process can be divided into three stages: a rapid growth zone, a slow growth zone, and a smooth zone, which reflected the process of backfill gradually compressed under the roof pressure. The results indicated that the impact of mining was gradually weakened as the backfill was

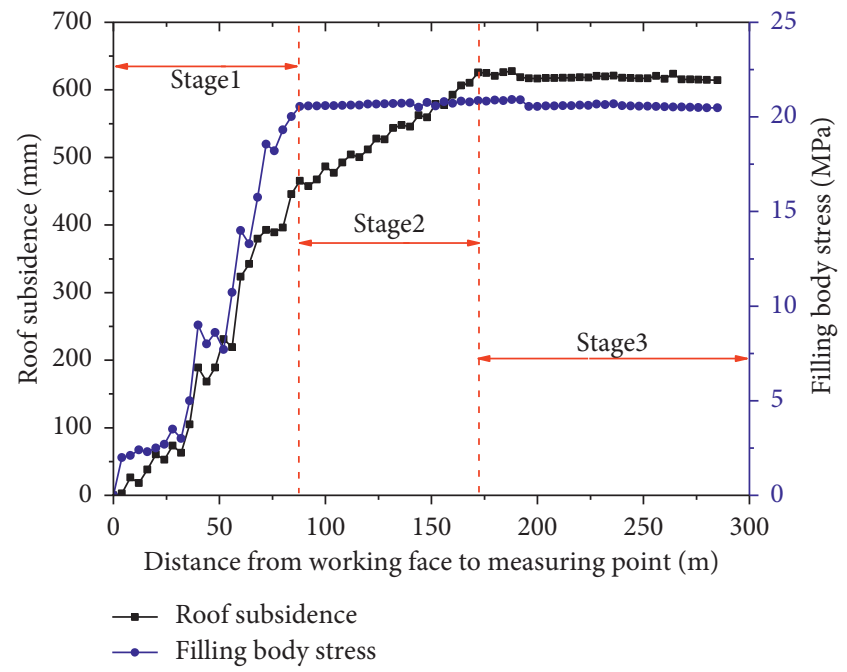

FIgURE 11: Roof dynamic subsidence measurement.

compacted, and the movement of roof tended to be stable. As the refilling proceeds to $250 \mathrm{~m}$ and the filling ratio controlled above $82.57 \%$, the movement of the roof in the rear of the goaf tends to be stable, effectively ensuring the safe operation of the stope.

5.2. Monitor Surface Subsidence. A monitor system of surface subsidence was designed with a monitor point spacing of $25 \mathrm{~m}$ and a control point spacing of $50 \mathrm{~m}$, based on the actual condition of mining area no. 930. Along the southnorth roads located on the west side of the Sunjia village and Wujia village and in the center of the Limiao village, 66 measuring points were installed facing measuring lines Z1-Z66. Along the road located on the south side of the Wujia village, 79 measuring points were installed facing measuring lines Q1-Q79. Along the east-west roads located on the north side of the Limiao village and Fengtai village, 22 measuring points were installed facing measuring lines J1-J22. Among these 22 measuring points, J17-J22 were distributed around the Fenghuangtai Ruin. Finally, along the south-north roads located on the east side of the Sunjia 


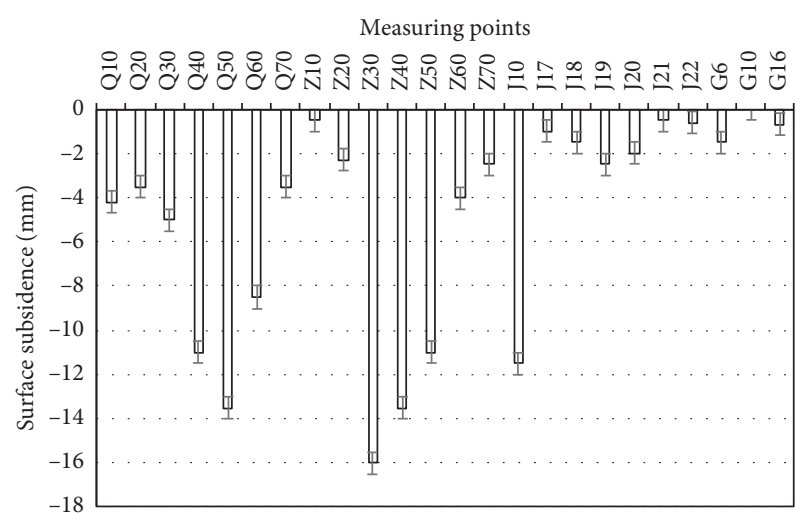

FIgURE 12: Surface subsidence monitor at the working area.

village and Wujia village, 35 measuring points were installed facing measuring lines T1-T35. Total station lead measurement was taken as the standard mode [26]. The measurement results are shown in Figure 12. Surface buildings were still well preserved until the extraction of working areas no. 9301 and no. 9302. It showed a relatively high surface subsidence at measuring points Q30-Q60 and Z30-Z50, located above the mined work surface, with a maximum surface subsidence of $16 \mathrm{~mm}$. At the locations between measuring points $\mathrm{J} 17$ and J20, the surface subsidence is less than $10 \mathrm{~mm}$, which indicates negligible impact on the buildings at Fenghuangtai Ruin.

\section{Conclusion}

(1) In this study, based on the theory of the probability integral method, the surface deformation characteristics were analyzed through theoretical calculation and numerical simulation with different depths and filling ratios. The maximum surface movement decreases logarithmically with increasing mining depth and decreases exponentially with increasing filling ratio. Regression analysis shows the relationship between surface subsidence amount and depth and filling rate: $w=3.61 e^{-0.47 \varphi}$ $-0.31 \ln (H)+0.12$.

(2) Based on the deformation resistance of the structures, the analysis suggests that the filling ratio should be maintained at no less than $82.5 \%$ for mining activity at mining area no. 930 in the Tangkou coal mine. Further damage analysis on the surface buildings confirmed that the control threshold of filling ratio designed in this study can effectively mitigate damage to surface buildings.

(3) An adequate backfill material density was ensured by optimizing the filling material composition, optimizing the tamping machine, controlling the presubsidence of the roof top, controlling the number of tamping processes, and controlling the height of filling material. The monitor result at mining area no. 930 in the Tangkou coal mine showed that the final filling ratio was controlled at $82.57 \%$, which exceeds the designed value of the refill body's filling ratio. During the backfilling process, no fracturing phenomenon or significant deformation of surface buildings was observed. These findings proved that the proposed strategy can effectively protect surface buildings such as Fenghuangtai Ruin during mining activity and ultimately realize safe and eco-friendly extraction of deep coal resources.

\section{Data Availability}

The data used to support the findings of this study are included within the article.

\section{Disclosure}

Wenyue Qi should be regarded as the co-first author.

\section{Conflicts of Interest}

The authors declare that there are no conflicts of interest regarding the publication of this article.

\section{Authors' Contributions}

Wenyue Qi contributed equally to this work.

\section{Acknowledgments}

The study was financially supported by the National Science Fund for Distinguished Young Scholars (51725403) and supported by the Independent Research Project of State Key Laboratory of Coal Resources and Safe Mining, CUMT (SKLCRSM19X006)

\section{References}

[1] M. C. He, H. P. Xie, S. P. Peng, and Y. D. Jiang, "Study on rock mechanics in deep mining engineering," Chinese Journal of Rock Mechanics \& Engineering, vol. 24, no. 16, pp. 2803-2813, 2005, in Chinese.

[2] J. Zhang, Q. Zhang, F. Ju, N. Zhou, M. Li, and Q. Sun, “Theory and technique of greening mining integrating mining, separating and backfilling in deep coal resources," Journal of China Coal Society, vol. 43, no. 2, pp. 377-389, 2018, in Chinese.

[3] H. Xie, G. Feng, J. U. Yang, and S. University, "Research and development of rock mechanics in deep ground engineering," Chinese Journal of Rock Mechanics \& Engineering, vol. 11, pp. 2161-2178, 2015, in Chinese.

[4] H. P. Xie, F. Gao, Y. Ju, M. Z. Gao, R. Zhang, and Y. N. Gao, "Quantitative definition and investigation of deep mining," Journal of China Coal Society, vol. 40, no. 1, pp. 1-10, 2015, in Chinese.

[5] H. P. Xie, H. W. Zhou, D. J. Xue, H. W. Wang, R. Zhang, and F. Gao, "Research and consideration on deep coal mining and critical mining depth," Journal of China Coal Society, vol. 37, no. 8, pp. 535-542, 2012, in Chinese.

[6] L. Yuan, "Thoughts and suggestions on cracking major scientific and technological problems in deep coal mining," Science \& Technology Review, vol. 34, no. 2, p. 1, 2016. 
[7] J. Zhang, Study on Strata Movement Controlling by Raw Waste Backfilling with Fully-Mechanized Coal Winning Technology and Its Engineering Applications, China University of Mining and Technology, Xuzhou, China, 2008.

[8] X. X. Miao and J. X. Zhang, "Analysis of strata behavior in the process of coal mining by gangue backfilling," Journal of Mining \& Safety Engineering, vol. 24, no. 4, pp. 379-382, 2007.

[9] H. D. Fan, D. Cheng, K. Z. Deng, B. Q. Chen, and C. G. Zhu, "Subsidence monitoring using d-insar and probability integral prediction modelling in deep mining areas," Survey Review, vol. 47, no. 345, pp. 438-445, 2015.

[10] H. Fan, K. Deng, C. Ju, C. Zhu, and J. Xue, "Land subsidence monitoring by D-InSAR technique," Mining Science and Technology (China), vol. 21, no. 6, pp. 869-872, 2011.

[11] H. D. Xue, K. Z. Deng, and C. G. Zhu, "Study on monitoring land subsidence in mining city based on coherent target smallbaseline InSAR," Safety in Coal Mines, vol. 37, no. 2, pp. 15-18, 2011, in Chinese.

[12] T. Jiřina and J.. Šperl, "Reduction of surface subsidence risk by fly ash exploitation as filling material in deep mining areas," Natural Hazards, vol. 53, no. 2, pp. 251-258, 2010.

[13] X. Chang, R. Wang, and J. Zang, Characteristic Analysis of Surface Subsidence in Deep Mining, Atlantis Press, Paris, France, 2014.

[14] S. Chen, D. Yin, F. Cao, Y. Liu, and K. Ren, "An overview of integrated surface subsidence-reducing technology in mining areas of China," Natural Hazards, vol. 81, no. 2, pp. 11291145, 2016.

[15] G.-l. Guo, X.-j. Zhu, J.-f. Zha, and Q. Wang, "Subsidence prediction method based on equivalent mining height theory for solid backfilling mining," Transactions of Nonferrous Metals Society of China, vol. 24, no. 10, pp. 3302-3308, 2014.

[16] Q. Zhang, "Roof control mechanism by coordination with backfilled body and backfill support in solid backfill mining technology," China University of Mining and Technology, Xuzhou, China, Doctoral dissertation, 2015.

[17] J. Zhang, Q. Zhang, Q. Sun, R. Gao, D. Germain, and S. Abro, "Surface subsidence control theory and application to backfill coal mining technology," Environmental Earth Sciences, vol. 74, no. 2, pp. 1439-1448, 2015.

[18] G. Q. He, L. Yang, and G. D. Ling, Mining Subsidence, China University of Mining and Technology Press, Xuzhou, China, 1991.

[19] J. Q. Xue, "Research of monitoring mine subsidence by D-InSAR technique," M.Sc. thesis, China University of Mining and Technology, Xuzhou, China, 2012.

[20] P.-x. Li, Z.-x. Tan, and K.-z. Deng, "Calculation of maximum ground movement and deformation caused by mining," Transactions of Nonferrous Metals Society of China, vol. 21, no. S3, pp. s562-s569, 2011.

[21] Z. S. Wang and K. Z. Deng, "Parameters identification of probability-integral method based on multi-scale kernel partial least-squares regression method," Chinese Journal of Rock Mechanics and Engineering, vol. 30, no. S2, pp. 38633870, 2011, in Chinese.

[22] L. Wang, "Study on strata movement mechanism and deformation prediction of coal mining with solid waste compacted filling," China University of Mining and Technology, Xuzhou, China, Doctoral dissertation, 2012.

[23] X. X. Miao, J. X. Zhang, and G. L. Guo, Method and Technology of Fully-Mechanized Coal Mining with Solid Waste Filling, China University of Mining and Technology Press, Xuzhou, China, 2010.
[24] J. F. Zha, W. K. Feng, and X. J. Zhu, "Research on parameters inversion in probability integral method by genetic algorithm," Journal of Mining \& Safety Engineering, vol. 28, no. 4, pp. 655-659, 2011.

[25] Ministry of Coal Industry, Specification for Coal Pillar Retention in Main Roadways Coal Pillar and Coal Mining under Buildings, Water Bodies and Railways, Coal Industry Press, Beijing, China, 2000.

[26] W. Qi, J. Zhang, N. Zhou, Z. Wu, and J. Zhang, "Mechanism by which backfill body reduces amount of energy released in deep coal mining," Shock and Vibration, vol. 2019, Article ID 8253269, 14 pages, 2019.

[27] Z. Tang, X. Dong, Y. Yang, and L. Ma, "Research on the relationship between grain composition and repose angle of coal gangue in Dongkuang mine, Heshan city, Guangxi, China," Journal of Earth Science, vol. 25, no. 2, pp. 309-314, 2014. 